\title{
PREVALENCE OF GASTROINTESTINAL PARASITES IN BUFFALOES IN THE STATE OF PARAÍBA AND THE FIRST REPORT OF Cystoisospora spp. IN BUFFALOES IN BRAZIL
}

\author{
PREVALÊNCIA DE PARASITOS GASTRINTESTINAIS EM BÚFALOS NO ESTADO DA PARAÍBA \\ E PRIMEIRO RELATO DE Cystoisospora spp. EM BÚFALOS NO BRASIL
}

\author{
V. L. R. VILELA ${ }^{1} *$, T. F. FEITOSA ${ }^{1}$, A. W. L. BRASIL ${ }^{2}$, R. N. PARENTONI ${ }^{2}$, R. A. BEZERRA ${ }^{1}$, \\ S. S. AZEVÊDO ${ }^{2}$
}

\begin{abstract}
SUMMARY
The aims of this study were to determine the prevalence of gastrointestinal parasites in buffaloes in the state of Paraíba, and to identify the risk factors associated with parasitic infection. The study involved 127 randomly selected buffaloes from 14 farms. Fecal Egg Count (FEC), fecal culture, and centrifugation-flotation in sucrose solution were performed. The prevalence of gastrointestinal parasites was $24.4 \%$ (31/127). ). Among the infected animals, $8.6 \%$ (11/127) had helminths, 13.4\% (17/127) had enteric protozoa, and 2.3\% (3/127) had both. The helminth genus identified most frequently in fecal culture was Haemonchus spp. (59\%), followed by Trichostrongylus spp. (34\%), and Oesophagostomum spp. (7\%). Eimeria spp. were present in 11.8\% (15/127), Giardia sp. in 2.4\% (3/127), and Cystoisospora spp. in 1.6\% (2/127) of the animals. Animal purchase from livestock auctions/fairs was identified as a risk factor for gastrointestinal parasites (odds ratio $=25.44 ; 95 \% \mathrm{CI}=2 ., 17-297.68 ; P=0.010$ ). Although approximately $25 \%$ of buffaloes in the state of Paraíba were infected with gastrointestinal parasites, the intensity of infection was low. To the best of our knowledge, this is the first study reporting the occurrence of Cystoisospora spp. in these animals in Brazil.
\end{abstract}

KEY-WORDS: Coccidia. Eimeria spp. Epidemiology. Haemonchus spp.

\section{RESUMO}

Objetivou-se determinar a prevalência de parasitos gastrintestinais em búfalos no Estado da Paraíba, e identificar os fatores de risco associados a essas infecções. O estudo foi realizado em 14 propriedades com criação de búfalos, utilizando 127 animais. Foram realizadas contagens de Ovos Por Grama de fezes (OPG), coproculturas e centrífugoflutuação em solução de sacarose. A prevalência de búfalos parasitados foi de 24,4\% (31/127), sendo que 8,6\% (11/127) apresentaram infecção apenas por helmintos, 13,4\% (17/127) apenas por protozoários entéricos e 2,3\% (3/127) apresentaram ambos. Nas coproculturas, Haemonchus spp. foi o gênero de helminto mais frequente (59\%), seguido por Trichostrongylus spp. (34\%) e Oesophagostomum spp. (7\%). Eimeria spp. esteve presente em 11,8\% (15/127) dos animais, Giardia sp. em 2,4\% (3/127) e Cystoisospora spp. em 1,6\% (2/127). A compra de animais em leilões/feiras agropecuárias foi identificada como fator de risco (odds ratio $=25,44 ; 95 \% \mathrm{CI}=2,17-297,68 ; P=0.010$ ). Embora aproximadamente $25 \%$ dos búfalos da Paraíba tenham apresentado infecções por parasitos gastrintestinais, a intensidade dessas infecções foi baixa. Concluiu-se que é alta a frequência de parasitas gastrintestinais em búfalos no Estado da Paraíba, em baixa intensidade. Este trabalho foi o primeiro a reportar a ocorrência de Cystoisospora spp. nestes animais no Brasil.

PALAVRAS-CHAVE: Coccídeos. Eimeria spp. Epidemiologia. Haemonchus spp.

\footnotetext{
${ }^{1}$ Department of Veterinary Medicine, Instituto Federal da Paraíba - IFPB. Avenida Presidente Tancredo Neves, s/n, Jardim Sorrilândia, Sousa-PB. Postcode: 58800-970.

${ }^{2}$ Post-Graduate Program in Veterinary Medicine, Universidade Federal de Campina Grande - UFCG. Avenida Universitária, s/n, Jatobá, Patos-PB. Postcode: 58700-970.

* Corresponding author. E-mail: vinicius.vilela@ifpb.edu.br
} 


\section{INTRODUCTION}

Commercial buffalo farming involves the production of the domestic Asian buffalo (Bubalus arnee), an animal characterized by precocity, gentleness, hardiness, longevity, and adaptability. These characteristics make the Asian buffalo a good alternative animal for the production of meat and milk. Initially introduced in northern Brazil, the Asian buffalo is gaining prominence in various Brazilian regions, including northeastern Brazil, for its hardiness (GONÇALVES, 2008).

Currently, Brazil has over one million heads of Asian buffalo, and there are 122.000 heads in the northeastern region. In Paraíba State, the total buffalo population is approximately 933 head (IBGE, 2012).

Management changes, increased animal density, and confinement have favored the introduction of infectious and parasitic diseases into herds. With these changes, gastrointestinal parasites have become more important in buffalo farming. Hematophagous nematodes and coccidian protozoa are the primary cause of parasitic disease. Both parasite groups have worldwide distribution and result in economic losses due to clinical disease, including anemia, listlessness, anorexia, diarrhea, and decreased production (DANTAS et al., 2015).

There is little information on gastrointestinal helminthiasis and coccidiosis in buffaloes in Brazil. The present survey was designed to determine the prevalence of gastrointestinal parasites in buffaloes in the state of Paraíba and to identify risk factors associated with gastrointestinal parasitic infection. We also report for the first time the presence of Cystoisospora spp. in buffaloes in Brazil.

\section{MATERIALS AND METHODS}

\section{Sampling}

Fourteen buffalo herds in the state of Paraíba, northeastern Brazil were involved in this study (Figure 1).

The number of animals to be sampled was calculated by the formula for simple random sampling according to the method of Thrusfield (2007):

$$
n=\frac{Z^{2} P(1-P)}{d^{2}}
$$

$\mathrm{n}=$ number of animals required to be sampled

$\mathrm{Z}=$ normal distribution value for the $95 \%$ confidence level

$\mathrm{P}=$ expected prevalence of $50 \%$ (for maximization of the sample)

\section{$\mathrm{d}=$ error of $10 \%$}

Murrah and mixed breed female milking buffaloes $(\mathrm{n}=127)$, aged $\geq 24$ months, were randomly selected from the 14 herds. On 13 farms, nine animals were examined and on one farm, 10 animals were examined.

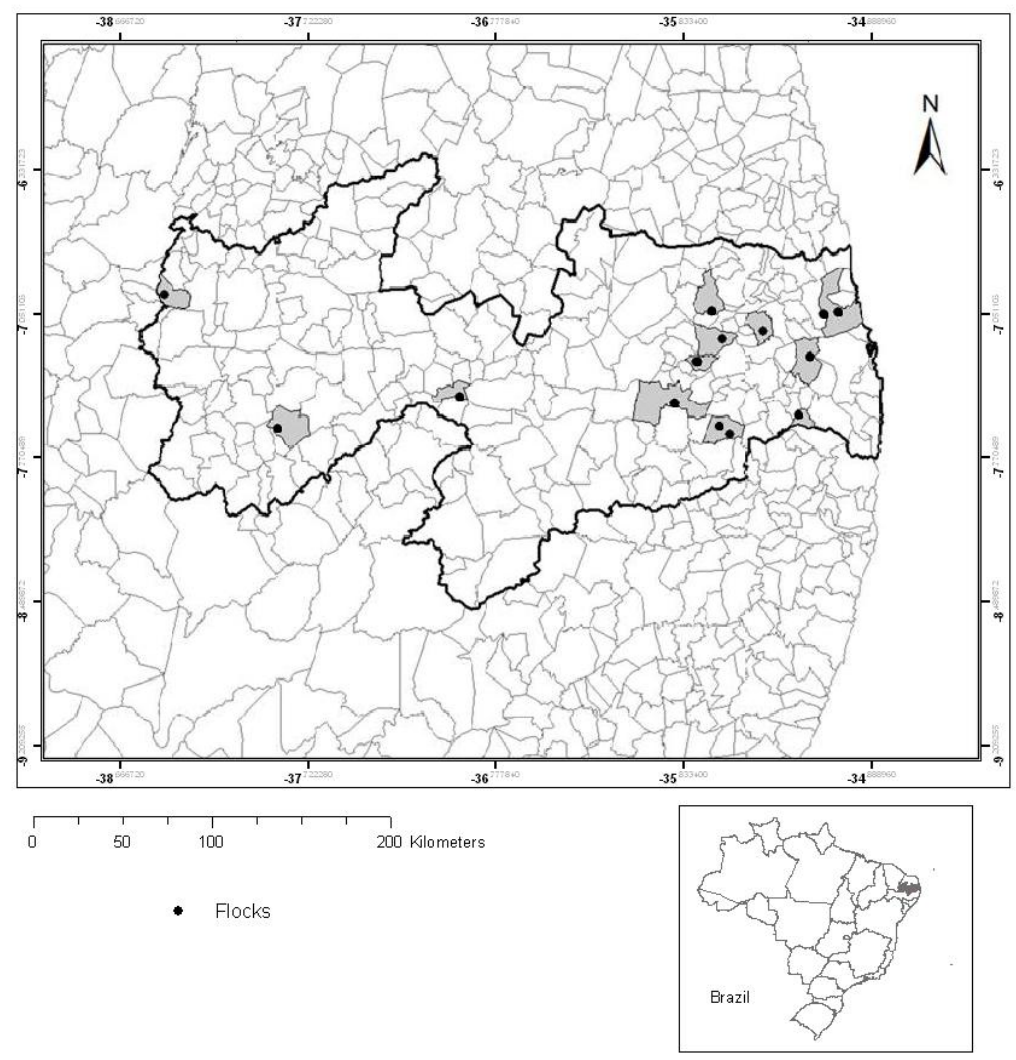

Figure 1 - Georeferenced buffalo herds in the state of Paraíba, northeastern Brazil. 
Fecal samples were collected directly from the rectal ampulla of the animals between October 2012 and June 2013. The samples were refrigerated and sent to the laboratory for analysis.

An epidemiological questionnaire was completed to identify risk factors. The variables analyzed were as follows: management system (semiintensive or extensive); type of milking (mechanical or manual); animal use (milk, meat, or mixed); number of milking per day (none, once, or twice a day); wildlife animals (yes or no); other animal species on the farm (cattle, goats/sheep, horses, poultry, pigs, cats, or $\operatorname{dog}$ ); presence of rodents (yes or no); rodent control (yes or no); miscarriages during the last 12 months (yes or no); water source (drinking troughs or watering points); feeding on native pasture (yes or no); pasture rental (yes or no); flooded areas (yes or no); animals purchased from livestock auctions/fairs (yes or no); veterinary assistance (yes or no); maternity pens (yes or no); and separation of young animals from adults (yes or no).

\section{Parasitological analyses}

To investigate helminthic eggs in the feces, fecal egg count (FEC) was performed according to the method of Gordon and Whitlock (1939). To determine the percentages of different helminths, fecal culture was performed according to the method of Roberts and O'Sullivan (1950), and larvae were identified using the method of Keith (1953).

To observe the presence of enteric protozoan oocysts and cysts, centrifugation-flotation in sucrose solution (modified Sheather's solution) was carried out (OGASSAWARA \& BENASSI, 1980). Sporulation was induced in fecal samples positive for coccidia, by the addition of a $2.5 \%$ solution of potassium dichromate in a 1:1 proportion (VIEIRA et al., 1999). For subsequent differentiation of the Eimeria spp. and Cystoisospora spp., samples were placed on Petri dishes, and stored for 15 days in BOD at $26^{\circ} \mathrm{C}$ and greater than $80 \%$ humidity. The level of helminthic infection was assessed according to the FEC values using the following classification (UENO \& GONÇALVES, 1998): mild (FEC<500); moderate
(FEC 500 to 1.500); severe (FEC 1.501 to 3.000); and fatal (FEC>3,000).

\section{Risk factor analysis}

Analysis of risk factors was done in two steps: univariate and multivariate analysis. The Chi-square test or Fisher's exact test was used for univariate analysis, and variables with $P \leq 0.20$ were used for multivariate logistic regression. The stepwise forward method was used for multivariable analysis (HOSMER $\&$ LEMESHOW, 2000). A $P$ value of 0.05 was considered significant in multivariate analysis. Data were analyzed with SPSS 20.0 software for Windows.

\section{Ethics Committee}

This research was submitted to the Research Ethics Committee of Universidade Federal de Campina Grande and obtained the protocol number 017/2012.

\section{RESULTS}

The frequency of buffaloes infected with parasites was $24.4 \%$ (31/127). Of the infected animals, $8.6 \%(11 / 127)$ had helminth infection; $13.4 \%(17 / 127)$ had enteric protozoan infection; and $2.3 \%$ (3/127) had both. On $71.4 \%(10 / 14)$ of farms, at least one animal had fecal parasites, and on these farms the percentage of infected animals ranged from $6.25 \%$ to $75 \%$. However, no animal showed clinical signs characteristic of parasitic diseases, such as anemia and diarrhea.

The FEC analysis demonstrated that all the animals positive for gastrointestinal helminths had mild infection. In fecal culture, Haemonchus spp. was the most frequent helminthic genus $(59 \%)$, followed by Trichostrongylus spp. (34\%), and Oesophagostomum spp. (7\%). In the centrifugation-flotation procedure, $11.8 \%(15 / 127)$ of the animals had Eimeria spp.; $2.4 \%$ (3/127) Giardia sp.; and 1.6\% (2/127) Cystoisospora spp. This is the first report of Cystoisospora spp. in buffaloes in Brazil (Figure 2).

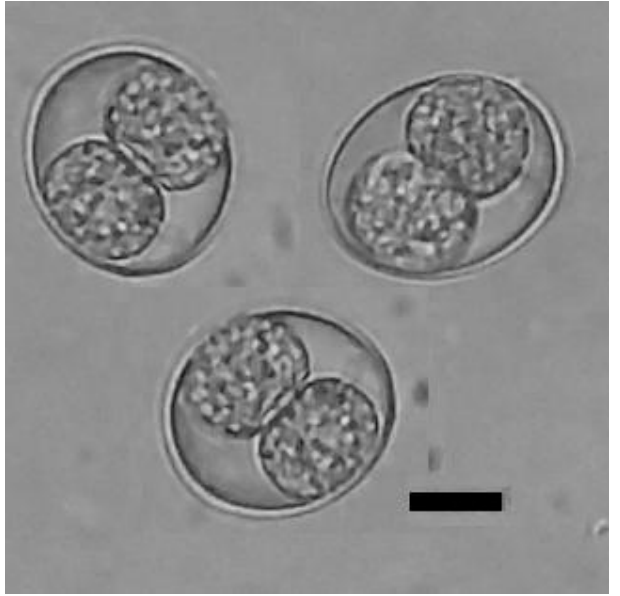

Figure 2 - Sporulated oocysts of Cystoisospora spp. in buffalo feces. Bar $=10 \mu \mathrm{m}$. 
Table 1 presents the results from the univariate $(P \leq 0.20)$ and multivariate $(P \leq 0.05)$ analysis for the risk factors with the greatest numbers of associated variables in relation to occurrences of gastrointestinal parasites. The variables of management system
$(P=0.01)$, animal use $(P=0.013)$, and animals purchased from livestock auctions/fairs $(P=0.045)$ were selected for the multivariate analysis. Animals purchased from livestock auctions/fairs was the only variable identified as a risk factor (odds ratio $=25.44$ ).

Table 1 - Univariate $(P \leq 0.2)$ and multivariate analysis $(P \leq 0.05)$ showing variables associated with the presence of gastrointestinal parasites in buffalo herds in the state of Paraíba, northeastern Brazil.

\begin{tabular}{|c|c|c|c|}
\hline \multicolumn{4}{|c|}{ Univariate analysis } \\
\hline Category & Total number of a & positive animals $(\%)$ & $P$ \\
\hline \multirow[t]{2}{*}{ Management system } & 27 & $1(3.7)$ & \\
\hline & 100 & $31(31)$ & 0.01 \\
\hline \multirow[t]{3}{*}{ Type of exploitation } & 93 & $29(31.2)$ & \\
\hline & 15 & $1(6.7)$ & \\
\hline & 19 & $1(5.3)$ & 0.013 \\
\hline Animals purchased at livestock auctions/fairsNo & 123 & $28(22.8)$ & \\
\hline Yes & 4 & $3(75)$ & 0.045 \\
\hline \multicolumn{4}{|c|}{ Multivariate analysis } \\
\hline Risk factor & Odds ratio & CI $95 \%$ & $P$ \\
\hline Animals purchased at livestock auctions/fairs & 25.44 & [2.17-297.68] & .010 \\
\hline
\end{tabular}

\section{DISCUSSION}

The prevalence of buffaloes parasitized by gastrointestinal protozoa and helminths in the state of Paraíba was $24.4 \%$. This was lower than previous studies from Pakistan by Bhutto et al. (2002) and Sahoo et al. (1991), reporting that $47 \%$ and $71.6 \%$ of the animals were positive for gastrointestinal helminths.

During fecal collection, no animal showed clinical signs of parasitic infection. In analyzing the FEC, $100 \%$ of the animals with gastrointestinal helminths had mild infection (FEC $<500)$. Bhutto et al. (2002) found higher levels of infection by helminths in buffaloes in Pakistan, where $36 \%$ of the parasitized animals had mild infection; $57 \%$ moderate infection; and $7 \%$ severe infection; however, there were no animals with fatal infection.

In this study, there was a low diversity of helminths parasitizing the evaluated buffaloes, and three were identified: Haemonchus spp., Trichostrongylus spp., and Oesophagostomum spp. cestodes and trematodes were not observed. Barbieri et al. (2010) found Toxocara spp., Strongyloides spp., and parasites from the superfamily Trichostrongyloidea (all nematodes), in buffaloes in the state of Rondônia, Brazil. Silva et al. (2014) found the predominance of parasites of the superfamily Trichostrongyloidea, Trichuris spp., Strongyloides papillosus, Toxocara vitulorum, Moniezia spp. and moderate levels of infection by Eimeria spp., in the state of Rio de Janeiro, Brazil. In Faisalabad, Pakistan, Anwer et al. (1996) identified nine different nematode genera in buffalo calves. These included Strongyloides spp., Toxocara spp., Haemonchus spp., Trichostrongylus spp., Ostertagia spp., Oesophagostomum spp., Bunostomum spp., Nematodirus spp., Cooperia spp., and cestodes of the genus Moniezia. The results from these investigations corroborate the present study regarding the absence of trematode species in buffaloes in this state.
In Brazil, unfavorable weather conditions for the survival of infective larvae in the environment occur most of the year. The Paraíba State is semi-arid, and characterized by high temperatures $\left(28-32^{\circ} \mathrm{C}\right)$ and low rainfall. Approximately $98.6 \%$ of the rainfall occurs during the rainy season, between January and May, and the remainder of the year is the dry season (VILELA et al., 2008).

In the centrifugation-floatation procedure, $11.8 \%$ of the animals had Eimeria spp. Infection. Similar results were found in the state of Rondônia (BARBIERI et al., 2010), Eimeria spp. was identified in $16.6 \%$ of the animals tested. Giardia sp. was observed in $2.4 \%$ of the animals. Ribeiro et al. (2000) identified Giardia sp. in diarrheal and non-diarrheal feces in buffaloes in the state of São Paulo, thus drawing special attention to this genus, due to its high zoonotic potential.

The present study reports for the first time the identification of Cystoisospora spp. in buffaloes in Brazil. Few studies have described parasitism by this genus in buffaloes, and it was first described in Turkey with a prevalence of $46 \%$ (NALBANTOGLU et al., 2008). For Cystoisospora spp., dogs, cats, and pigs are the definitive hosts. Infection occurs after ingestion of sporulated oocysts in feces or ingestion of infected tissues (URQUHART et al., 1998). We observed the presence of dogs on the farms helping with the management of the buffalo, suggesting that the dogs may be a source of infection in buffaloes.

Animals purchased from livestock auctions/fairs were identified as a risk factor for gastrointestinal parasites. This variable (lack of biosecurity) is a classic risk factor for infectious and parasitic diseases. Purchase animals arrive parasitized from the farms of origin and are introduced into the herd without proper quarantine, biosecurity measures, or sanitary control. The purchased animals become a source of infection. 


\section{CONCLUSION}

Although nearly $25 \%$ of buffaloes tested in the state of Paraíba were infected with gastrointestinal parasites, the intensity of infection was low, and clinical signs were not observed. The occurrence of Cystoisospora spp. has been reported for the first time in Brazil. Based on the risk factor analysis, it is recommended that biosecurity and sanitary controls should be implemented before purchased animals are introduced into the herd.

\section{REFERENCES}

ANWER, H. A.; HAYAT, C. S.; AMIR, M. I. Prevalence of gastrointestinal helminthiasis and comparative efficacy of anthelmintics in parasitized buffalos calves. Pakistan Veterinary Journal, v.16, p.160-163, 1996.

BARBIERI, F. S.; BRITO, L. G.; FIGUEIRÓ, M. R.; BANDEIRA, P. F.; NASCIMENTO, A. X. Parasitismo natural por helmintos gastrointestinais em búfalos criados em Presidente Médici, Rondônia Brasil. [Boletim de pesquisa e desenvolvimento] Empresa Brasileira de Pesquisa Agropecuária - Rondônia; 2010.

BHUTTO, B.; PHULLAN, M. S.; RAHAMATULLAH, R.; SOOMRO, A. H. Prevalence of Gastro-Intestinal Helminths in Buffalo Calves. Journal of Biological Sciences, v.2, n.1, p.43-45, 2002.

DANTAS, P. C. S.; LIMA, D. S.; OLIVEIRA, F. J.; CALASANS, T. A. S.; PORTO, A. G.; CARVALHO, C. D.; JERALDO, V. L. S.; ALLEGRETTI, S. M.; MELO, C. M. Ocorrência de parasitoses gastrintestinais em vacas leiteiras e respectivos bezerros durante o período de amamentação, na fazenda São Paulino, Município de Itapicuru/BA. Scientia Plena, v.11, n.4, 2015.

GONÇALVES, O. Características de criação de búfalos no Brasil e a contribuição no marketing no agronegócio bubalino. 2008. 130p. Tese (Doutorado em Qualidade e Produtividade Animal) - Faculdade de Zootecnia e Engenharia de Alimentos, Universidade de São Paulo, Pirassununga-SP.

GORDON, H. M.; WITHLOCK, H. V. A. New tecnique for counting nematode eggs in sheep faeces. Journal of the Council Scientific and Industrial Research, v.12, n.1, p.50-52, 1939.

HOSMER, D. W.; LEMESHOW, S. Applied logistic regression. $2^{\text {nd }}$ ed New York: John Wiley \& Sons; 2000. IBGE, Instituto Brasileiro e Geografia e Estatística. Sistema IBGE de Recuperação Automática - SIDRA. [online]. 2012 [cited 2013 Dec 11]. Available from: <http://www.sidra.ibge.gov.br/bda/pecua/default.asp?t= $2 \& \mathrm{z}=\mathrm{t} \& \mathrm{o}=24 \& \mathrm{u} 1=1 \& \mathrm{u} 2=1 \& \mathrm{u} 3=1 \& \mathrm{u} 4=1 \& \mathrm{u} 5=1 \& \mathrm{u} 6=1$ $\& u 7=1>$.
KEITH, R. K. The differential of the infective larval of some common nematode parasites of cattle. Australian Journal Zoology, v.2, p.223-230, 1953.

NALBANTOGLU, S.; SARI, B.; CICEK, Z.; KARAER, Z. Prevalence of coccidian species in the water buffalo (Bubalus bubalis) in the province of Afyon, Turkey. Acta Veterinaria Brunensis, v.77, p.111-116, 2008.

OGASSAWARA, S.; BENASSI, S. Infecção experimental de gatos com coração bovino parasitado por Sarcocystis spp. Arquivos do Instituto Biológico, v.47, n.1-2, p.27-32, 1980.

RIBEIRO, M. G.; LANGONI, H.; JEREZ, J. Á.; LEITE, D. S.; FERREIRA, F.; GENNARI, S. M. Identificação de enteropatógenos em bezerros búfalos, com e sem diarréia, do Vale do Ribeira, Estado de São Paulo, Brasil. Brazilian Journal of Veterinary Research Animal Science, v.37,p.159-165, 2000.

ROBERTS, F. H. S.; O'SULLIVAN, J. P. Methods for egg counts and larval cultures for strongyles infesting the gastrointestinal tract of cattle. Australian Journal of Agricultural Research, v.1, p.99-102, 1950.

SAHOO, N.; MISRA, A.; DEY, P. C. A note on the incidence of helminthiasis in buffalo calves with particular reference to ascariasis. Orissa Veterinary Journal, v.16, p.52-54, 1991.

SILVA, J. B.; CORREAA, F. N.; DE MEIRELES, G. S.; FLAUSINO, W; FONSECA. A. H. Estudo transversal da frequência de helmintos e protozoários em búfalos no estado do Rio de Janeiro, Brasil. Revista Brasileira de Medicina Veterinária, v.36, n.3, p.239-243, 2014.

THRUSFIELD, M. Veterinary epidemiology. $3^{\mathrm{a}}$ ed. Oxford: Blackwell Science, 2007.

UENO, H.; GONÇALVES, P. C. Manual para diagnóstico de helmintoses de ruminantes. $4^{\mathrm{a}}$ ed. Tokyo: Japan International Cooperation Agency; 1998.

URQUHART, G. M.; ARMOUR, J.; DUNN, A. M.; JENNINGS, F. W. Parasitologia Veterinária. $2^{\mathrm{a}}$ ed. Guanabara Koogan, 1998.

VIEIRA, L. S.; CAVALCANTE, A. C. R.; XIMENES, L. J. F.; Evolution of infection with Eimeria species in hair sheep reared in Sobral, Ceara State, Brazil. Revista de Medicina Veterinária, v.150, n.6, p.547-550, 1999.

VILELA, V. L. R.; SOLANO, G. B.; ARAÚJO, M. M.; SOUSA, R. V. R.; SILVA, W. A.; FEITOSA, T. F.; ATHAYDE, A. C. R. Ensaios preliminares para avaliação do método FAMACHA $\odot$ em condições de semi-árido Paraibano. Revista Brasileira de Parasitologia Veterinária, v.17, p.154-157, 2008. 